\title{
DNA Polymorphisms in 3'UTR and Intron-9 Region of PPARGC1A Gene and its Association with Milk Production Traits in Gaolao Cattle
}

\author{
Y.B. Sathe, D.S. Kale, Jaya Singh, D.V. Patil, P.G. Koringa ${ }^{1}$, J.P. Korde, M.R. Jawale
}

10.18805/IJAR.B-4791

\begin{abstract}
Background: PPARGC1A gene mediates expression of genes involved in gluconeogenesis and is regarded as a prominent candidate gene governing the effect of milk fat in dairy bovines. The study was planned to identify DNA polymorphisms in the PPARGC1A gene in Gaolao Cattle and to find their association with milk production traits in Gaolao cattle.

Methods: The blood was collected from 224 purebred Gaolao cattle from farm and field along with test day milk from each cow for estimating milk components. Genomic DNA was assessed using phenol-chloroform extraction method and Kits. PCR-RFLP, PCRSSCP and direct DNA sequencing methods were used to identify polymorphism.

Result: PPARGC1AG1- Nhel locus of 3'UTR region were polymorphic with allele frequency for A alleles as 0.84 and for allele B as 0.16. In studied animals, significant differences were not observed for milk traits between genotypes at PPARGC1A-Nhel locus. The analysis at PPARGC1AG4-SSCP revealed no significant differences in milk traits; however sequencing revealed SNP. PPARGC1AG1Nhel genotype-based sequencing revealed T>C SNP at $263^{\text {rd }}$ position 02 computational SNPs viz; C-T at $263^{\text {rd }}$ position and A-T at $268^{\text {th }}$ position. The identified variation at the PPARGC1A gene may aid in identifying associations for development of markers for selection and genetic improvement.
\end{abstract}

Key words: Gaolao cattle, Milk traits, PCR-RFLP, PPARGC1A, Sequencing, SSCP.

\section{INTRODUCTION}

Traditional and advanced principles and tools in animal genetics and breeding will revolutionize future dairy cattle breeding for productivity enhancement. Molecular marker technology has paved the way for identifying the candidate gene regions underlying economic traits like milk production in dairy animals. The imputation of these identified variants information in genetic evaluation increases selection accuracy and improves genetically essential traits like milk yield and milk composition. Various researchers are currently working on genomic research to enhance milk productivity by conducting candidate gene polymorphism and association studies (Rahayu et al., 2019; Liu et al., 2020; Korkuc et al., 2021).

Peroxisome proliferator-activated receptor-gamma coactivator 1 alpha (PPARGC1A) gene mediates the expression of genes involved in gluconeogenesis. It is a prominent functional and positional candidate governing the potential quantitative trait locus effect for milk fat in dairy bovines. PPARGC1A gene is located on the $6^{\text {th }}$ bovine autosome and to date, many SNPs related to milk production traits have been identified. Various studies have reported that SNPs like PPARGC1Ac.1892T>C and PPARGC1AC.3359 A $>C$ affect milk yield traits (Weikard et al., 2005; Khatib et al., 2007; Komisarek et al., 2009; Viale et al.,2017)).

Gaolao cattle is a relatively fair milk yielder indigenous cattle breed well adapted to harsh, adverse and tropical climatic conditions of the Vidarbha region of Maharashtra
Department of Animal Genetics and Breeding, Nagpur Veterinary College, Maharashtra Animal and Fishery Sciences University, Nagpur-440 006, Maharashtra, India.

1Department of Animal Biotechnology, College of Veterinary Science and Animal Husbandary, Anand Agricultural University, Anand-388 001, Gujarat, India.

Corresponding Author: D.S. Kale, Department of Animal Genetics and Breeding, Nagpur Veterinary College, Maharashtra Animal and Fishery Sciences University, Nagpur-440 006, Maharashtra, India. Email: deepakkaleccmb@gmail.com

How to cite this article: Sathe, Y.B., Kale, D.S., Singh, J., Patil, D.V., Koringa, P.G., Korde, J.P. and Jawale, M.R. (2022). DNA Polymorphisms in 3'UTR and Intron-9 Region of PPARGC1A Gene and its Association with Milk Production Traits in Gaolao Cattle. Indian Journal of Animal Research. DOI: 10.18805/IJAR.B-4791.

Submitted: 29-09-2021 Accepted: 15-01-2022 Online: 04-03-2022

state of India. Gaolao Breed is known by her prominent frontal bone and short stumpy horns. Candidate genes have been consistently reported from different studies for their association with the milk production traits (Strucken et al., 2015). PPARGC1A was analyzed using a genome-wide association study approach to identify significant SNPs strongly linked with milk traits. Because of this, it is needed to study PPARGC1A gene to develop a database of variations linked with milk traits for their possible further use in improving productive and healthy Gaolao population. 
DNA Polymorphisms in 3'UTR and Intron-9 Region of PPARGC1A Gene and its Association with Milk Production Traits...

\section{MATERIALS AND METHODS}

\section{Experimental animals and data collection}

The adult milking Gaolao cows were selected for the current study from Gaolao farmers of the breeding tract. Around 05 $\mathrm{ml}$ blood was collected from 224 purebred adults milking Gaolao cattle using sterile needle and anticoagulant. The collected blood was stored at $4^{\circ} \mathrm{C}$ temperature until DNA isolation. Milk in the quantity of around $20 \mathrm{ml}$ was collected from 135 adult milking cows to estimate milk components like fat $\%$, protein $\%, \mathrm{SNF} \%$ and Lactose $\%$, etc.

Nucleic acid extraction, quality and quantity estimation

The nucleic acid extraction was carried out using phenol, chloroform-isoamyl alcohol extraction protocol (Sambrook and Russel, 2001) with minor modifications and also using Kits. The quality and quantity were checked using a spectrophotometer and agarose gel electrophoresis. The genomic DNA was stored at $-20^{\circ} \mathrm{C}$ in a freezer which was later used to prepare a working solution for PCR reactions.

\section{Polymerase chain reaction}

The primers were custom synthesized from a company for their use in amplification of $3^{\prime} U T R$ and Intron-9 regions of PPARGC1A gene. The information about the gene region, amplicon product size, annealing temperature, primer sequence is given in Table 1. The PCR amplification of 3'UTR and intron-9 regions of PPARGC1A gene was carried out using PPARGC1AG1 and PPARGC1AG4 primers. The PCR amplification conditions for PCR components and thermal cycling conditions were optimized in the laboratory. PCR amplification was performed in a volume of $25 \mu \mathrm{l}$ containing $12.5 \mu \mathrm{l} 1 \mathrm{X}$ PCR buffer, $10 \mathrm{pM}$ of each primer, $4 \%$ DMSO and 50-100 ng genomic DNA. The cycling protocol was as follows: $5 \mathrm{~min}$ at $95^{\circ} \mathrm{C}, 32$ cycles of denaturing at $94^{\circ} \mathrm{C}$ for 45 seconds, annealing at $\mathrm{Tm}^{\circ} \mathrm{C}$ for 45 seconds (Table 1 ) and extension at $72^{\circ} \mathrm{C}$ for 45 seconds, with a final extension at $72^{\circ} \mathrm{C}$ for $7 \mathrm{~min}$. The PCR amplifications were assessed in $1.5 \%$ agarose gel electrophoresis by loading $4 \mu \mathrm{l}$ of PCR product mixed with ethidium bromide $(10 \mathrm{mg} / \mathrm{ml})$. The stained PCR gels were visualized using UV fluorescence and documented in a gel documentation system (BR Biochem).

\section{PCR-RFLP analysis}

The quality PCR amplicons were used for PPARGC1AG1-
Nhel PCR-RFLP analysis in 224 animals of Gaolao cattle. The restriction digestion of the regions of the PPARGC1A gene was carried out using $5 \mathrm{U} / \mu \mathrm{l}$ of Nhel restriction enzyme and $0.1-0.5 \mu \mathrm{g}$ PCR product of each primer and incubated at $37^{\circ} \mathrm{C}$ temperature for 14 hours. Later restriction enzyme digested PCR products were resolved in $3.5 \%$ agarose gel electrophoresis using ethidium bromide staining and later documented under GelDoc system.

\section{PCR-SSCP analysis}

SSCP analysis was carried out in 43 animals with the vertical electrophoresis apparatus (Bio-rad). The $8 \%$ polyacrylamide gel was prepared using acrylamide: bisacrylamide (49:1), 10X TBE buffer, glycerol and autoclaved distilled water and electrophoresis was run at 150 volts for $5-6 \mathrm{hrs}$ at $25^{\circ} \mathrm{C}$ temperature. After completing the electrophoresis run, the SSCP gel was stained using the standard $0.01 \%$ silver nitrate staining procedure with some modifications in the laboratory.

\section{SNP analysis using bioinformatics tools}

The obtained DNA sequences were analyzed using various bioinformatics tools (BioEdit BLAST, Clustal Omega) to detect nucleotide substitutions.

\section{Statistical analysis}

Genotype and allele frequencies were estimated using POPGENE Ver-sion 1.31 (Yeh and Boyle, 1997). The obtained gene and genotype frequencies were tested for deviation from Hardy-Weinberg equilibrium using a Chisquare test (Devlin and Risch, 1995). The relationship between the milk component and genotype was tested using one-way ANOVA. The mathematical model is as below,

$$
\mathrm{GT}_{\mathrm{ijk} / \mathrm{m}}=\mu+M Y_{i}+\mathrm{F}_{\mathrm{j}}+\mathrm{S}_{\mathrm{k}}+\mathrm{L}_{\mathrm{l}}+\mathrm{P}_{\mathrm{m}}++\mathrm{e}_{\mathrm{ijk} / \mathrm{m}}
$$

Where,

$\mathrm{GT}_{\mathrm{ijk} / \mathrm{m}}$ is the observed genotype.

$\mu=$ Overall mean.

$M Y_{i}=$ Fixed effect of Milk Yield.

$F_{i}=$ Fixed effect of Fat \%.

$\mathrm{S}_{\mathrm{k}}=$ Fixed effect of the SNF \%.

$L_{1}=$ Fixed effect of Lactose $\%$.

$P_{m}=$ Fixed effect of the Protein \%.

$\mathrm{e}_{\mathrm{ijklm}}=$ Residual(error) effect of each observation

All the analysis was done by SPSS Version 20 (IBM, USA).

Table 1: Name, region, nucleotide sequences, product sizes and annealing temperature of primers used for amplification of PPARGC1A gene in Gaolao cattle.

\begin{tabular}{llll}
\hline Names of primer & Region of gene & Primer nucleotide sequence & Product size $(\mathrm{bp}) /$ Tm $\left({ }^{\circ} \mathrm{C}\right)$ \\
\hline PPARGC1AG1 & 3'UTR & F:5'GCGAGCACGGTGTTACATTACTAAGGAGAGTTGGCTAG3' & $357 \mathrm{bp} / 60^{\circ} \mathrm{C}$ \\
& & R:5'GTTGTGTTGCACTCAATGGAC3' & \\
PPARGCA1G4 & Intron-9 & F:5'CATAGCCGGCGCCCCAGGTAAGATGCACGTTGGC-3' & $195 \mathrm{bp} / 50^{\circ} \mathrm{C}$ \\
& & R: 5'-CTGGTACTCCTCGTAGCTGTC-3' & \\
\hline
\end{tabular}

Where, F- Forward primer, R- Reverse primer.

Tm- Annealing temperature. 
DNA Polymorphisms in 3'UTR and Intron-9 Region of PPARGC1A Gene and its Association with Milk Production Traits...

\section{RESULTS AND DISCUSSION}

Information about particular candidate genes like PPARGC1A due to their relevant biological functions, the polymorphism details and their effects on economic traits will help understand a molecular pathway that leads to productivity variation between different individuals of the established breed.

\section{PPARGC1AG1- Nhel PCR-RFLP results}

The $357 \mathrm{bp}$ fragment of 3'UTR region of PPARGC1A gene was amplified using PPARGC1AG1 primer (Fig 1) and digested using Nhel enzyme (Khatib et al., 2007). The PPARGC1AG1- Nhel PCR-RFLP analysis in 224 animals revealed three different genotypes, i.e., AA with $357 \mathrm{bp}$ band size, $A B$ with $357 \mathrm{bp}, 317 \mathrm{bp}$ and $40 \mathrm{bp}$ band sizes and $\mathrm{BB}$ with 317 bp and 40 bp band sizes (Fig 2). PPARGC1AG1Nhel locus was found polymorphic for SNP (C.3359 A>C) with genotype frequency for $A A$ genotype as $0.69, A B=0.30$ and $\mathrm{BB}=0.01$. The allele frequency for the $A$ alleles was found at 0.84 and for the allele, $B$ was 0.16 at the
PPARGC1AG1- Nhel locus (Table 2). The non-significant chisquare value indicated that all the genotypic frequencies in the population were not in Hardy-Weinberg equilibrium $(P>0.01)$. The current study's findings are in line with the results reported by Basak et al. (2019) in 146 Deoni breeds of cattle for $\mathrm{AA}, \mathrm{AC}$ and $\mathrm{CC}$ genotypes with frequencies as $0.75,0.21$ and 0.04 , respectively. For this locus, KowalewskaŁuczak et al. (2010) also found two genotypes i.e. AA and AC as 0.76 and 0.24 respectively in 181 Jersey cows.

However, for the University of Wisconsin (UW) dairy cattle population at this SNP (C.3359 A>C), Khatib et al. (2007) reported genotype frequencies as $0.163,0.506$ and 0.331 for $A A, A C$ and $C C$, respectively and as $0.123,0.430$ and 0.447 , for the Cooperative Dairy DNA Repository (CDDR) population respectively.Weikard et al. (2005) identified genotype frequencies of $\mathrm{AA}, \mathrm{AC}$ and $\mathrm{CC}$ genotype as $0.15,0.58$ and 0.27 , respectively in German Holstein cattle. Similarly, in South Anatolian Red (SAR) indigenous cattle breeds of Turkey, Atila et al. (2014) reported two genotypes, i.e., $\mathrm{AA}$ and $\mathrm{AC}$, with 0.23 and 0.77 frequencies,

Table 2: Allelic and genotypic frequencies at PPARGC1AG1- Nhel locus in Gaolao cattle population.

\begin{tabular}{lcccccccc}
\hline \multirow{2}{*}{ Loci } & \multirow{2}{*}{ N } & \multirow{2}{*}{ Genotypes } & \multicolumn{2}{c}{ No. of genotypes } & \multicolumn{2}{c}{ Frequency } & \multirow{2}{*}{$\chi^{2}$} & \\
\cline { 3 - 6 } & & & Observed & Expected & Genotypic & Allelic & & \\
\hline PPARGC1A G1- Nhel & 224 & AA & 154 & 156.8792 & 0.69 & $0.84(\mathrm{~A})$ & 2.004305 & 0.156853 \\
& & AB & 67 & 61.2416 & 0.30 & - & & \\
& & BB & 03 & 5.8792 & 0.01 & $0.16(\mathrm{~B})$ & & \\
\hline
\end{tabular}

${ }^{* * P}<0.01$.

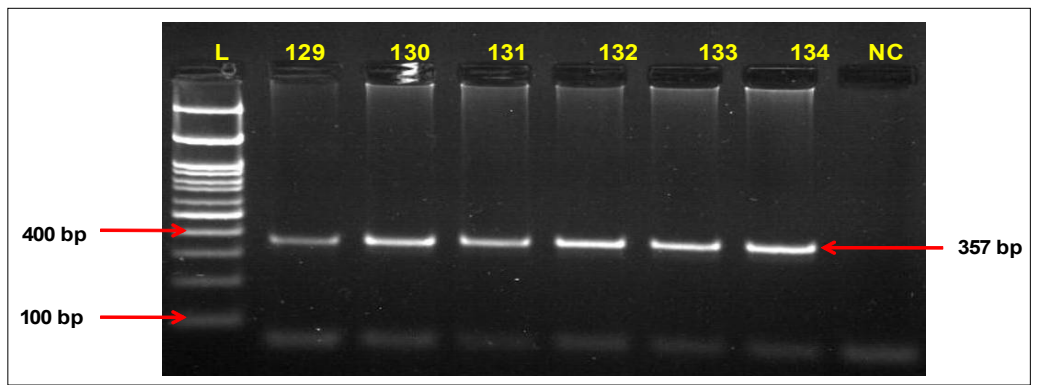

Fig 1: PCR amplification of 357 bp PPARGC1A 3' UTR gene fragment (PPARGC1A G1 primers) resolved in $1.5 \%$ agarose gel electrophoresis in Gaolao cattle.

Where, GB 129-134= Gaolao cattle number, NC- Negetive control, L= 100 bp DNA ladder (Himedia).

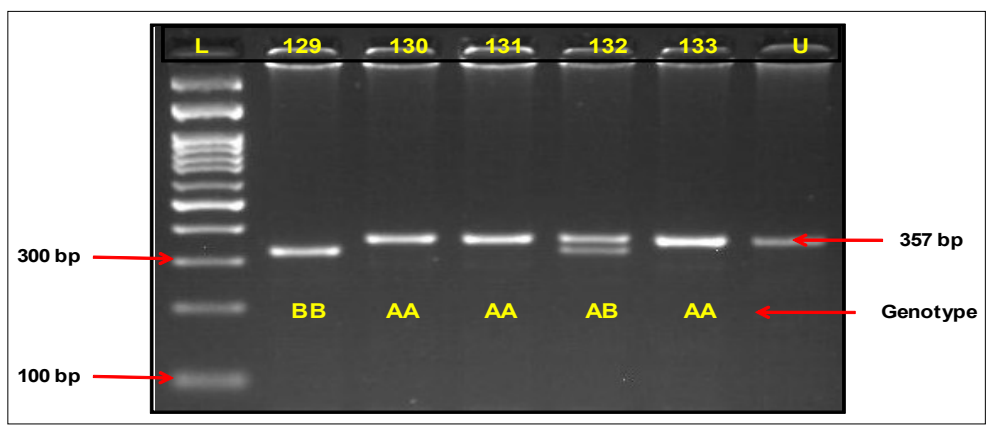

Fig 2: PCR-RFLP polymorphism (PPARGC1A G1-Nhel) 3' UTR region of PPARGC1A gene resolved in $3.5 \%$ agarose gel electrophoresis in Gaolao cattle.

Where, L= 100 bp DNA ladder (Himedia), GB 129-133= Gaolao cattle number, U- Uncut, AA, AB, BB= Genotype. 
DNA Polymorphisms in 3'UTR and Intron-9 Region of PPARGC1A Gene and its Association with Milk Production Traits...

Table 3: Average effect of milk production traits at polymorphic PPARGC1AG1- Nhel locus in Gaolao cattle.

\begin{tabular}{lccccccc}
\hline Genotype & N & Fat $\% \pm$ SE & SNF $\% \pm$ SE & Lactose $\% \pm$ SE & Protein $\% \pm$ SE & MY \pm SE & LN \pm SE \\
\hline AA & 94 & $4.34 \pm 0.45$ & $8.57 \pm 0.05$ & $4.39 \pm 0.04$ & $3.15 \pm 0.03$ & $4.16 \pm 0.18$ & $2.63 \pm 0.14$ \\
AB & 39 & $4.09 \pm 0.10$ & $8.61 \pm 0.08$ & $4.46 \pm 0.06$ & $3.09 \pm 0.05$ & $3.64 \pm 0.26$ & $2.90 \pm 0.26$ \\
BB & 02 & $3.85 \pm 0.15$ & $8.65 \pm 0.25$ & $4.23 \pm 0.12$ & $2.94 \pm 0.05$ & $4.00 \pm 2.00$ & $2.00 \pm 0.00$ \\
Total & 135 & $4.26 \pm 0.32$ & $8.58 \pm 0.04$ & $4.40 \pm 0.03$ & $3.13 \pm 0.03$ & $4.01 \pm 0.15$ & $2.70 \pm 0.12$ \\
\hline
\end{tabular}

respectively. In East Anatolian Red (EAR) breeds, they found two genotypes, i.e., $\mathrm{AA}$ and $\mathrm{AC}$, with frequencies as 0.40 and 0.60 , respectively. However, Pasandideh et al. (2015) identified $A A, A C$ and $C C$ genotypes with frequency as 0.38 , 0.52 and 0.10 , respectively, in 398 Iranian Holstein cows. In the current study, no significant differences were found in milk production traits between all genotypes (Table 3 ) in 135 experimental animals. However, Khatib et al. (2007) found that $A$ allele was associated with protein percentage in both populations for SNP A/C at position 3359 in the 3'UTR and milk traits in UW and CDDR populations. Similarly, in other studies (Weikard et al.,2005), the PPARGC1A- c.3359A>C SNP, have been reported to affect milk yield traits.

\section{SNP detection at polymorphic PPARGC1AG1- Nhel PCR- RFLP Locus}

Three polymorphic genotypes were sequenced which revealed T-C SNP at $263^{\text {rd }}$ position in the PPARGC1A gene sequence (Fig 3). The alignment of 279 bp PPARGC1AG1 sequence with Bos taurus reference sequence (KM111251.1) revealed 02 computational SNPs viz; C-T at $263^{\text {rd }}$ position and A-T at $268^{\text {th }}$ position. BLAST analysis of 279 bp sequence revealed sequence identity of $98.93 \%$ with cattle, buffalo and $98.21 \%$ with sheep and $97.96 \%$ with goat respectively. Distance tree was generated using pairwise alignments between obtained 279 bp sequence in Gaolao cattle with related database sequences (Fig 4). Researchers have performed the alignment analysis of bovine PPARGC1A which exhibited a similarity of $94 \%$ for humans and $91.1 \%$ for mice and rats (Weikard et al., 2005).

\section{PPARGC1AG4-SSCP and SNP detection}

The PCR-SSCP analysis of 195 bp amplified fragment of PPARGC1Agene (Fig 5) was carried out in 43 samples using $8 \%$ PAGE. The silver staining of PPARGC1AG4 gene fragments revealed polymorphism with two SSCP patterns (A and $B$ ) at PPARGC1AG4-SSCP locus (Fig 6). The frequency of pattern $A$ was 0.35 and of pattern $B$ was 0.65 in 43 Gaolao animals. The analysis of SSCP Patterns

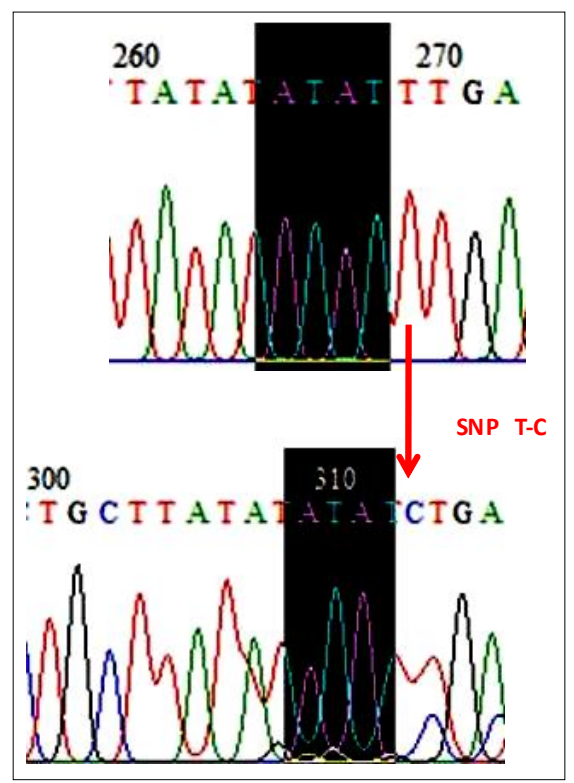

Fig 3: SNP T-C at $263^{\text {rd }}$ position in 279 bp sequence of PPARGC1A G1 amplified PCR product in Gaolao cattle population.

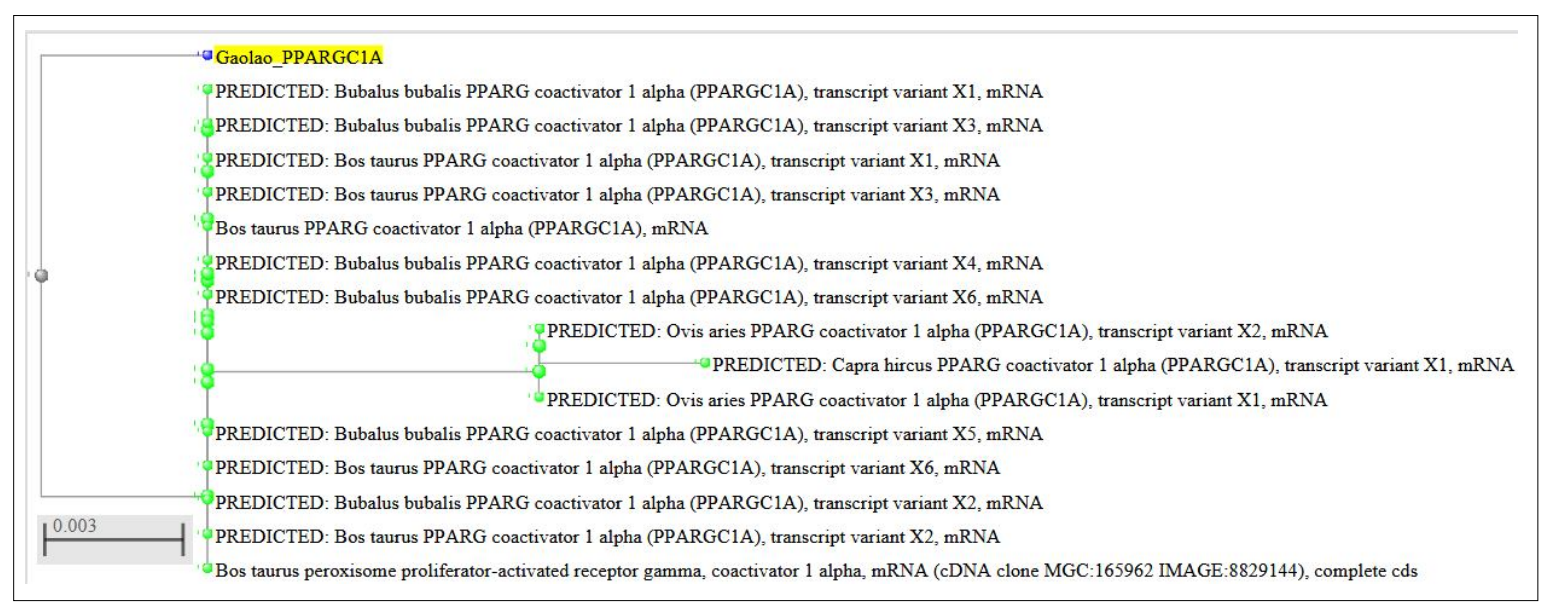

Fig 4: BLAST tree based on pairwise alignment between 279 bp query sequence obtained using PPARGC1A G1 primers and relevant data sequence. 
DNA Polymorphisms in 3'UTR and Intron-9 Region of PPARGC1A Gene and its Association with Milk Production Traits...

Table 4: Average effect of milk traits at PPARGC1AG4-SSCP locus in Gaolao cattle.

\begin{tabular}{llcccccc}
\hline SSCP pattern & $\mathrm{N}$ & Fat $\% \pm$ SE & SNF $\% \pm$ SE & Lactose $\% \pm$ SE & Protein $\% \pm$ SE & Milk yield $\pm S E$ & LN \pm SE \\
\hline A & 15 & $3.97 \pm 0.12$ & $8.46 \pm 0.10$ & $4.38 \pm 0.08$ & $3.09 \pm 0.05$ & $3.90 \pm 0.33$ & $3.27 \pm 0.33$ \\
B & 28 & $4.24 \pm 0.11$ & $8.66 \pm 0.09$ & $4.37 \pm 0.06$ & $3.15 \pm 0.06$ & $3.95 \pm 0.32$ & $2.50 \pm 0.32$ \\
Total & 43 & $4.15 \pm 0.08$ & $8.86 \pm 0.07$ & $4.37 \pm 0.05$ & $3.13 \pm 0.03$ & $3.93 \pm 0.24$ & $2.76 \pm 0.24$ \\
\hline
\end{tabular}

* indicates statistically significant at $0.05(p<0.05)$ level.

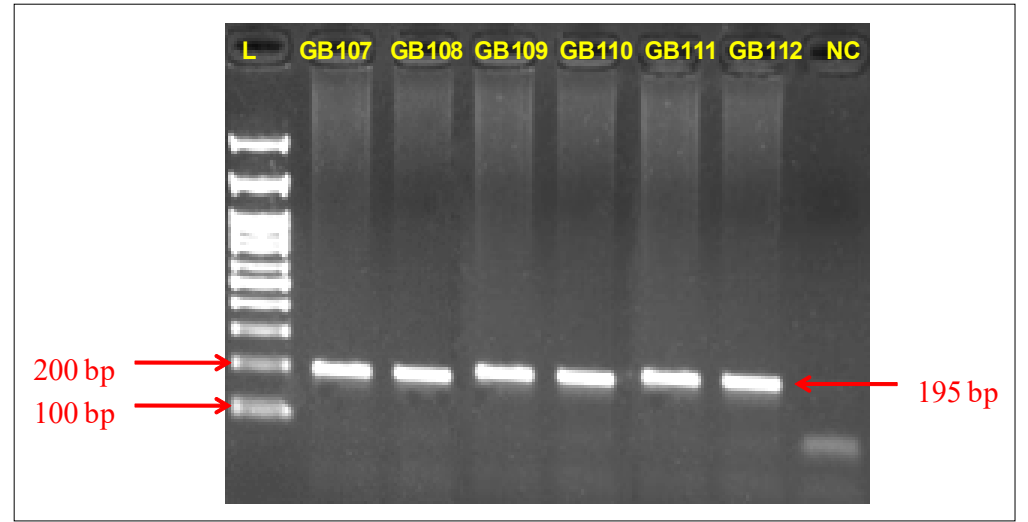

Fig 5: PCR amplification of $195 \mathrm{bp}$ fragment of Intron-9 region of PPARGC1A gene (PPARGC1A G4 primers) resolved in $1.5 \%$ agarose gel electrophoresis in Gaolao cattle.

Where, GB 107-112= Gaolao cattle number, NC- Negetive control, L= 100 bp DNA ladder (Himedia).

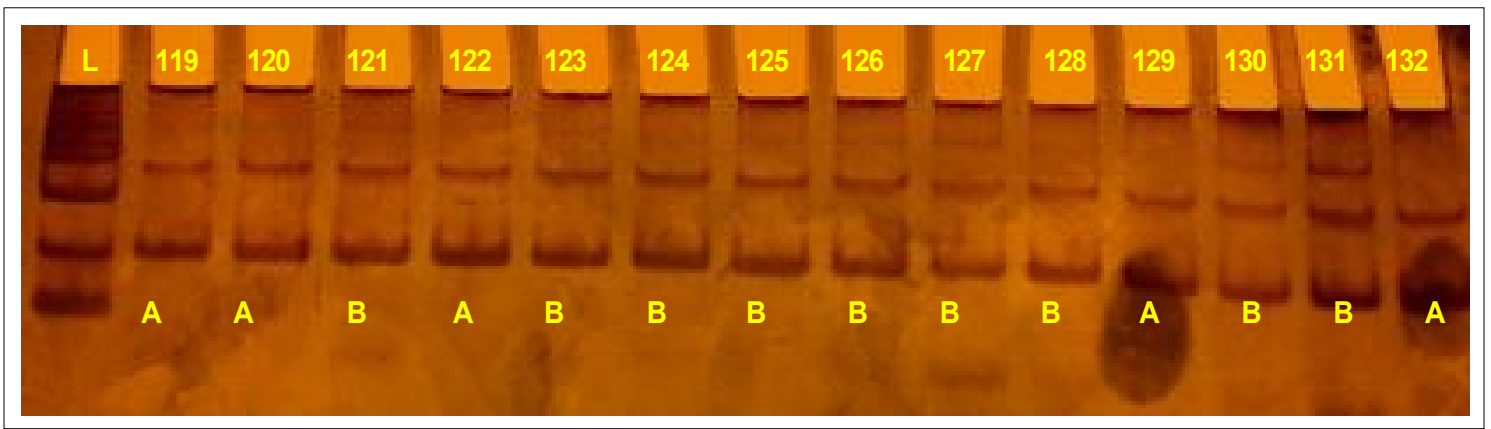

Fig 6: Polymorphic PPARGC1A G4-SSCP pattern in intron 9 region of 195 bp gene fragment of PPARGC1A gene (PPARGC1A G4 primers) in Gaolao cattle and visualised using $8 \%$ non-denaturing PAGE stained by silver staining.

Where, A- SSCP pattern-1, B- SSCP pattern-2 and L- Ladder. GB 119-132= Gaolao cattle sample numbers.

revealed no significant differences in milk production traits (Table 4). However, it was found that individuals with SSCP patterns B exhibited relatively more fat $\%$, SNF\%, lactose $\%$, protein $\%$ and milk yield than patterns A. Two SSCP patterns $A$ and $B$ were sequenced which revealed nucleotide substitution indel SNP N-T at $116^{\text {th }}$ position in Gaolao Cattle. However, Weikard et al. (2005) revealed SNP c. 1892+19T>C in intron 9 of PPARGC1A gene exhibiting three genotypes TT, TC and CC with frequencies as $0.01,0.30$ and 0.68 respectively in German Holstein. Khatib et al. (2007) reported three genotypes TT, TC and CC with frequencies as $0.019,0.65$ and 0.331 respectively and a significant association between milk yield and milk fat traits. Schennink et al. (2009) screened Holstein Friesian Cattle for SNP c. $1892+19 T>C$ and reported frequency of $C$ allele as 0.75 and $\mathrm{T}$ allele as 0.25 , respectively. Boleckova et al. (2012) also reported the frequency of $C$ allele as 0.80 and $T$ allele as 0.20 , respectively, in Czech Fleckvieh cattle. KowalewskaŁuczak et al. (2010) also reported frequency of $C$ allele as 0.37 and $\mathrm{T}$ allele as 0.63 respectively in 181 Jersey cows and revealed no significant association. Komisarek et al. (2009) also reported the frequency of $C$ allele as 0.73 and $T$ allele as 0.27 respectively in Polish HF cows and revealed no relation of T allele and milk yield traits. Alim et al. (2012) also reported the frequency of $\mathrm{C}$ allele as 0.69 and $\mathrm{T}$ allele as 0.31 respectively in Chinese HF cows and revealed the relation of TT genotype with milk higher protein level. Basak et al. (2019) also reported the frequency of the C allele as 0.635 and T allele as 0.365 , respectively, in Deoni cattle. Atila et al. (2014) also reported the frequency of $C$ allele as 0.65 and T allele as 0.35 respectively in South Anatolian Red cattle. Atila et al. (2014) also reported the frequency of $C$ allele as 0.80 and T allele as 0.20 , respectively, in East Anatolian Red cattle. They revealed the relation of $\mathrm{CC}$ genotype with high 
DNA Polymorphisms in 3'UTR and Intron-9 Region of PPARGC1A Gene and its Association with Milk Production Traits...

milk fat\%. Pasandideh et al. (2015) also reported the frequency of $C$ alleles as 0.56 and $T$ alleles as 0.44 respectively in Iranian Holstein cows. They revealed the relation of TT genotype with high-fat percentage and TC genotype was associated with milk protein.

\section{CONCLUSION}

PPARGC1AG1- Nhel locus PCR-RFLP locus at 32 UTR region of PPARGC1A gene was polymorphic for SNP (C.3359 $A>C$ ) with frequency for the $A$ alleles as 0.84 and allele B allele as 0.16 in 224 Gaolao cattle population; however, no significant differences were observed in milk traits between in all genotypes at PPARGC1A-Nhel polymorphism. The comparison in PPARGC1AG4-SSCP Patterns revealed no significant differences in milk production traits. PPARGC1AG1- Nhel PCR-RFLP genotype and PPARGC1AG4-SSCP pattern-based sequencing revealed SNPs in the PPARGC1A gene sequence in Gaolao cattle population. The identified genetic variation information at these loci in the PPARGC1A candidate gene of Gaolao cattle will aid in future studies for identification of significant associations for the development of markers for selection and improvement in milk production traits.

\section{ACKNOWLEDGEMENT}

The authors duly acknowledge the financial support to the present work by the funding agency SERB-DST, New Delhi, under Core Research Grant Scheme (File No. EMR/2017/ 000323), to Dr. D.S. Kale, PI and Asstt. Professor at Deptt. of AGB, NVC, MAFSU, Nagpur. The help rendered from members of Gaolao Breeder's Association and from State A.H. Deptt.; Dr. Pradnya Gulhane, Dr. Madhavi and Mr. Kheche, Mr. Lahulkar, Mr. Baghel, Mr. Chandankhede, Mr. Pravin Galhat and Mr. Prasanna Bamb in the survey, phenotyping and collection of blood and milk samples of Gaolao cattle from the breeding tract is duly acknowledged.

\section{Conflict of interest: None.}

\section{REFERENCES}

Alim, M.A., Fan, Y., Xie, Y., Wu, X., Sun, D., Zhang, Y., Zhang, S., Zhang, Y., Zhang, Q., Liu, L. (2012). Single nucleotide polymorphism (SNP) in PPARGC1A gene associates milk production traits in Chinese Holstein cattle. Pakistan Veterinary Journal. 32(4): 609-612.

Atila, A., Gulhan, T., Iraz, A., Feraye, E.G., Hasret, Y., Kemal, O. (2014). Genotype and allele frequencies of polymorphisms in ABCG2, PPARGC1A and OLR1 genes in indigenous cattle breeds in Turkey. Acta Veterinaria-Beograd. 64(1): 73-80.

Basak, S., Das, D.N., Mundhe, U.T. (2019). CYP11B1 and PPARGC1A genes polymorphism controlling reproductive traits and estimation of breeding value of first lactation milk yield in Bos indicus (Deoni) cattle. Veterinarski Arhiv. 89: 463-479.

Boleckova, J., Matejickova, J., Stipkova, M., Kyselova, J., Barton, L. (2012). The association of five polymorphisms with milk production traits in Czech Fleckvieh cattle. Czech Journal of Animal Science. 57(2): 45-53.
Botstein, D., White, R. L., Skolnick, M., Davis, R.W. (1980). Construction of a genetic linkage map in man using restriction fragment length polymorphisms. American Journal of Human Genetics. 32(3): 314-331.

Devlin, B. and Risch, N. (1995). A comparison of linkage disequilibrium measures for fine-scale mapping. Genomics. 29: 311322.

Khatib, H., Zaitoun, I., Wiebelhaus-Finger, J., Chang, Y.M., Rosa, G.J.M. (2007). The Association of bovine PPARGC1A and OPN genes with milk composition in two independent Holstein cattle populations. Journal of Dairy Science. 90: 2966-2970.

Komisarek, J. and Dorynek, Z. (2009). Effect of ABCG2, PPARGC1A, OLR1 and SCD1 gene polymorphism on estimated breeding values for functional and production traits in Polish Holstein-Friesian bulls. Journal of Applied Genetics. 50: 125-132.

Korkuć, P., Arends, D., May, K., König, S., Brockmann, G.A. (2021). Genomic loci affecting milk production in German Black Pied cattle. Frontiers in Genetics. 12: 275.

Kowalewska-Luczak., Kulig, H., Kmiec, M. (2010). Associations between the bovine PPARGC1A gene and milk production traits. Czech Journal of Animal Science. 55 (5): 195-199.

Liu, L., Zhou, J., Chen, C. J., Zhang, J., Wen, W., Tian, J., Zhang, Z.. Gu, Y. (2020). GWAS-based identification of new loci for milk yield, fat and protein in Holstein Cattle. Animals. 10: 2048. doi:10.3390/ani10112048.

Pasandideh, M., Mohammadabadi, M.R., Esmailizadeh, A.K., Tarang, A. (2015). Association of bovine PPARGC1A and OPN genes with milk production and composition in Holstein cattle. Czech Journal of Animal Science. 60 (3): 97-104.

Rahayu, A., Hartatik, T., Purnomoadi, A., Kurnianto, E. (2019). Association of single nucleotide polymorphisms in the fatty acid synthase, LOC514211 and fat mass and obesityassociated genes with milk traits in Indonesian-Holstein dairy cattle. Veterinary World. 12(7): 1160-1166.

Sambrook, J. and Russell, D.W. (2001). Molecular Cloning: A Laboratory Manual. Cold Spring Harbour Laboratory Press, pp 616.

Schennink, A., Bovenhuis, H., Leon-Kloosterziel, K., Arendonk, V.J., Viske, M. (2009). Effect of polymorphisms in the FASN, OLR1, PPARGC1A, PRL and STAT5A genes on bovine milk-fat composition. Animal Genetics. 40: 909-916.

Strucken, E., Laurenson, Y., Brockmann, G.A. (2015). Go with the flow biology and genetics of the lactation cycle. Frontiers in Genetics. 6: 118.

Viale, E., Tiezzi, F., Maretto, F., De Marchi, M., Penasa, M., Cassandro, M. (2017). Association of candidate gene polymorphisms with milk technological traits, yield, composition and somatic cell score in Italian HolsteinFriesian sires. Journal of Dairy Science. 100: 7271-7281.

Weikard, R., Kuhn, C., Goldammer, T., Freyer, G., Schwerin, M. (2005). The bovine PPARGC1A gene: Molecular characterization and association of an SNP with variation of milk fat synthesis. Physiological Genomics. 21: 1-13.

Yeh, F.C. and Boyle, T.J.B. (1997). Population genetic analysis of codominant and dominant markers and quantitative traits. Belgian Journal of Botany. 129: 157-163. 